\title{
JUSTIFICATION OF MODELS OF CHANGING PROJECT ENVIRONMENT FOR HARVESTING GRAIN, OILSEED AND LEGUME CROPS
}

Anatolii Tryhuba Lviv National Agrarian University, Ukraine

E-mail: atryguba55@gmail.com

Oleh Bashynskyi Lviv National Agrarian University, Ukraine E-mail: olegboi0202@gmail.com

Yevhen Medvediev Volodymyr Dahl East Ukrainian National University, Ukraine E-mail:medvedev.ep@gmail.com

Serhii Slobodian State Agrarian and Engineering University in Podilya, Ukraine E-mail: sergessb75@gmail.com

Dmytro Skorobogatov State Agrarian and Engineering University in Podilya, Ukraine E-mail: dskorobogatov@i.ua

Submission: 30/11/2018 Revision: 14/12/2018 Accept: 05/01/2019

\section{ABSTRACT}

An analysis of the condition of implementation of projects in agricultural production is carried out. The disadvantages of existing methods and models of planning of the content and time of execution of works in the projects, which mostly do not take into account the changing components of their project environment, are substantiated. The proposed methodology for justifying the models of a changing project environment for harvesting grain, oilseed and legume crops is based on the analysis of official statistics of agrometeorological stations and involves the implementation of production experiments, which makes it possible to increase the accuracy of the results. It has been established that the dewy periods of time in the projects for the collection of early oilseeds, cereals and legumes are characterized by 
DOI: 10.14807/ijmp.v10i7.922

a probabilistic distribution of the time of occurrence of dew and its duration. The indicated regularity and the established correlation relationship between the occurrence of dew and its duration are the main components of the model. The substantiated model of the pink period of time allows to take into account the changing events of the project environment and to improve the quality of the content management process and the time of performance of the harvesting work.

It is established that the deficit of humidity in the air, in which the performance of harvesting is effective, changes over the course of the day by parabolic dependence. Its maximum value depends on the agrometeorologically acceptable duration of the works in the projects of harvesting early oilseeds, grain and legume crops, which is the basis for substantiating the model of the air humidity deficit and taking into account its impact on the implementation of works in these projects. The obtained results of the research are the basis of development of simulation models of projects for the collection of early oilseeds, grain and legume crops to improve the accuracy of determining the use indicators and resource requirements for the implementation of these projects. The obtained models increase the quality of management decision making in the projects of harvesting early oilseeds, grain and legume crops.

Keywords: model, project environment, project, harvesting, grain crops

\section{INTRODUCTION}

Currently, in Ukraine there is a problem of harvesting early grain crops (TRYHUBA, et al., 2013). In the process of reforming the state's economy in agrarian production, a situation has arisen that from year to year, the harvesting park for grain harvesting decreases. This leads to the need for a centralized harvesting of early grain crops by technological service enterprises (ANDERSON; 1988).

A number of projects should be implemented to efficiently centralize the collection of early grain crops. These projects can be divided into strategic ones related to the formation of a combine park, and tactical ones, which are aimed at increasing the efficiency of the use of the existing combine park. During the implementation of these projects a number of tasks arise, the solution of which requires the development of appropriate scientific and methodological principles (SILVEIRA, et al., 2018). 
One of the tasks of tactical projects for centralized harvesting of early grain crops is to manage their content and time (SYDORCHUK, et al., 2012). This task is relevant both in scientific and in practical terms. At the same time, the variable design environment is important for reconciling the content and the time of the performed work. Its variability is due to the stochastic effect of natural and climatic conditions, on the territory where projects for the collection of early oilseeds, cereals and legumes are implemented.

In order to take into account, the changing impact of the project environment on the content and timing of projects for the collection of early oilseeds, grain and legume crops, scientific and methodological principles of their research should be developed and the models of natural and climatic conditions for a given territory should be substantiated.

\section{LITERATURE REVIEW}

Managing the content and timing of projects is one of the main areas of knowledge of project management. A number of standards have been developed to manage these processes, in particular PMI, PMBOK (BUSHEW, 2009). In addition, a number of scientific works related to the improvement of the content management methodology and the implementation time of projects have been carried out (BUSHEW, 2000; CLELAND; IRELAND, 2007; FRAME, 1994; KERZNER, 2003).

The analysis of the current scientific and methodological principles of content management and time in the projects indicates that they did not consider causal relationships between work and events with probable time of occurrence, which makes it impossible to unambiguously define the hierarchical structure of these works, as well as to construct a grid graph of their implementation (ANDRADE, 2009; HEIZER; RENDER, 1996).

Known works (SYDORCHUK, et al., 2011; TRYHUBA, et al., 2018), which substantiated the expediency of forecasting the changing components of the project environment. However, these works relate to various subject areas of the projects (ROMANO, 2003), which does not take into account the specificity of projects for the collection of early oilseeds, cereals and legumes.

It should also be noted that current methods and patterns of content management and time do not take into account the specifics of early oilseed, grain 
DOI: 10.14807/ijmp.v10i7.922

and legume harvesting projects (LERMEN, et al., 2016). In particular, they do not take into account the changing natural and climatic conditions for a given territory, where projects for the collection of early oilseeds, cereals and legumes are implemented. Consequently, the justification of the models of a changing project environment for harvesting grain, oilseed and legume crops is very relevant both in scientific and in practical terms.

The purpose of the article is to substantiate the models and to establish the regularities of changing the variable project environment of grain, oilseed and legume crops harvesting projects.

\section{METHODOLOGY}

The project environment, as already mentioned, in projects for the collection of early cereals, oilseeds and legumes is divided into components agrometeorological, substantive and production. The agrometeorological component of the design environment determines the events in the spaces that characterize the possibility of performing harvesting in the fields.

The events of the agrometeorological component are at the same time derived from the first events of the first kind, characterized by the appearance of the crop in separate fields, as well as the basic events regarding the possibility of performing harvesting projects. In other words, in the absence of a crop in certain fields, agrometeorological conditions are of no interest to project managers, because the collection work in this case is not fulfilled.

Only after the onset of the stage of harvesting in one or another field in the harvesting of early crops is a need to consider the agrometeorological component of the project environment. This circumstance is fundamental to the development of a project and modeling the performance of harvesting in it.

The agrometeorological component of the design environment characterizes alternately formed time intervals with weathered and mild conditions.

Predominant conditions are called agrometeorological conditions; in which it is possible to assemble early crops. This is a lack of weather, which during the harvest season is characterized by the number and duration of the corresponding intervals of time. Between moderate intervals, there are periods of rainy weather. Thus, the 
DOI: 10.14807/ijmp.v10i7.922

duration of the implementation of the harvesting project is characterized by a sequence of sweeping and tumultuous intervals of time (TRYHUBA, et al., 2012).

To manage the work in early cropping projects, this sequence is one of the main reasons for ensuring the adequacy of their modeling, which is carried out in this work to determine the number of fields that are awaiting collection each day and in a certain way characterize the situational program of projects (AMORIM, et al., 2017). The simulation of combine harvesting during the harvest season of individual projects is carried out on the basis of known information (TRYHUBA; SHOLUDKO; 2011; PIERRE; ROBILLARD; ROBILLARD, 2000), but because of this, the model of weathered and non-seasonal time intervals in the project environment system is not considered here.

The air humidity deficit in harvesting early oilseeds, grain and legume crops significantly affects the productivity of combine harvesters in the seasonal program fields, and therefore - at the time of execution of the relevant work, which should be taken into account in the process of managing the content and time of projects. The change in productivity is conditioned by the fact that the speed of combine harvesters in the formation is determined by the moisture content of the grain-stem mass.

An increasing air humidity deficit, the moisture content of the grain stem mass decreases, which is the reason for the increase in the speed of combine harvesting in the field. causes an increase in the moisture content of the grain stem mass and, as a consequence, a decrease in the speed of the combine. In view of this, the failure to take into account the design of the early crop harvesting project, the effect of the humidity deficit on the pace of agony impossible to work towards its adequacy to real projects that can lead to erroneous management decisions.

In order to reflect the effect of the humidity deficit on the model of the project on its course, first of all, research was carried out on its daily changes.

The empirical basis for such researches was the data of the Yavoriv Agrometeorological Station of Lviv Oblast, collected over the past 35 years in relation to changes in air humidity deficiencies every 3 hours during the harvesting of early crops (from July 1 to August 15). The methodical feature of processing statistics on the change in the air humidity deficit during certain harvesting seasons 
DOI: 10.14807/ijmp.v10i7.922

was that only a part of the information on the change in this indicator was taken into account which was related to exceeding its value by more than $4 \mathrm{hPa}$. Such a choice was due to the fact that the collection of these early crops can be effectively carried out only under such agrometeorological conditions. Otherwise, grain (seed) is obtained at excessively high humidity, as well as deterioration of its threshing machine, which leads to the loss of the cultivated yield (SYDORCHUK; TRYHUBA; PANIURA; et al., 2010).

The graphic analysis of the change in the air humidity deficit has made it possible to assert that during the light days the value of the recorded data exceeds 4 $\mathrm{hPa}$ for a certain period of time, which has its beginning and end on the daily axis of time. In the conditions of the Small Polesie of the Lviv region, the air humidity shortage exceeds $4 \mathrm{hPa}$ once a day. The terms of the transition of the air humidity deficit through the marking $4 \mathrm{hPa}$ mostly coincide with the terms of the appearance and drying of dew (in some cases, the difference does not exceed $0.5 \mathrm{~h}$ ), which became the reason to assume in the model the terms of appearance and debris expiration of the transition of the air humidity deficit through the mark $4 \mathrm{hPa}$.

A number of projects are implemented in agrarian production and they are integrated with each other. In particular, such integrated projects include those relating to the cultivation of crops and the central harvesting. To implement such projects, management processes are carried out, which include initialization and closure, planning, execution and control. During the management of integrated harvesting projects, the special processes are carried out. Appropriate tools were developed for their implementation (methods, models, techniques).

They should take into account technological interconnections between products and the probable behavior of the project environment. The structure of the processes of content management and the time of execution of works in the projects harvesting of cereals, oilseeds and legumes is determined by the functions they are predetermine. As a result, all processes of managing the content and time of projects for harvesting grain, oilseed and legume crops are classified by us according to two classification features: 1) for validity; 2) for affiliation to the project components. Process management of harvesting cereals, oilseeds and legumes are divided into basic and secondary by validity. The main processes are those that are regulated in relation to content management and time of project execution. These include 
DOI: 10.14807/ijmp.v10i7.922

processes identification of components of the design environment and justification of their models.

\section{ANALYSIS OF RESULTS}

\subsection{Results of the substantiation of the model of the dewy intervals of time in the system of the project environment}

An important component of agrometeorological conditions that is taken into account when managing harvesting operations in early oilseed, grain, and legume harvesting projects are the pinkish periods of time, which mostly occur in the evening hours of the calendar day. For the development of the model of this component in the system of events of the project environment, the time of occurrence $\left(t_{p}^{n}\right)$ and completion $\left(t_{p}^{3}\right)$ of dew of each day of the prevailing intervals of time is investigated.

These data are recorded by agrometeorological stations. In fact, in each study, data from the Yavoriv Agrometeorological Station in the Lviv region was used. Data from the official documents (TCX-1 and KM-1 form) from this station for the years 1980-2015 on the beginning of the appearance and duration of the pseudoscale periods during the harvesting of early crops (from July 1 to August 15) became the source information for the development of the model these gaps in the project environment.

On the basis of processing by methods of mathematical statistics according to the well-known method (TRYHUBA, et al., 2018) data on the onset $\left(t_{p}^{n}\right)$ of dew, the distribution of this time on the daily axis of time is constructed and its statistical characteristics are determined. As a result, they obtained and found that the empirical distribution of the time of occurrence of dew is described by the Weibull law (Graph 1), whose density function is written by the equation:

$f\left(t_{n}^{p}\right)=0,466 \cdot\left(\frac{t_{n}^{p}-16,8}{2,778}\right)^{0,295} \exp \left[-\left(\frac{t_{n}^{p}-16,8}{2,778}\right)^{1,295}\right]$.

Note that for this distribution, there are the following statistical characteristics: 1) estimation of the mathematical expectation - $19,90 \mathrm{~h} ; 2$ ) the estimate of the mean 
DOI: 10.14807/ijmp.v10i7.922

square deviation is $1,466 \mathrm{~h} ; 3$ ) estimating the scale parameter - $a=2,064$; evaluation of the form parameter $-b=1,315$.

Investigating the duration of this interval, we found that it is a probabilistic value. At the same time, an average correlation between the beginning of dew (tпp) and its duration $\left(\Delta t_{p}\right)$ was found (Graph 2). The presence of this connection has a physical explanation - given the fact that every mild day with the onset of the morning and the rise of the sun over the horizon is the dew evaporation, then the time interval from this moment to the time of the dew will be more than dew earlier.

The regression line in this case is written by the equation:

$\Delta t_{p}=-0,781 t_{\Pi p}+27,34$.

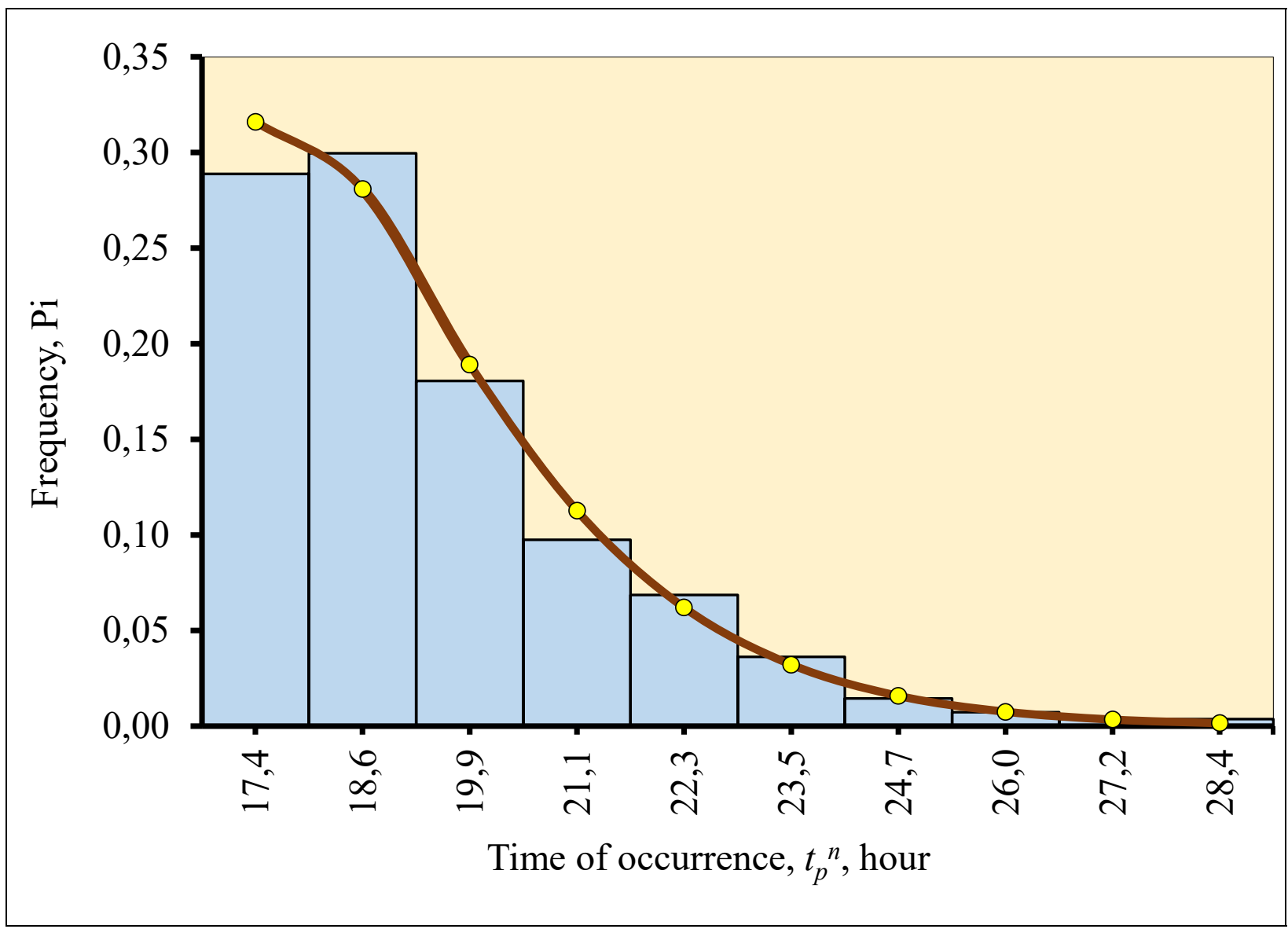

Graph 1: Histogram and theoretical curve of the time dew occurrence Source: the authors (2018) 


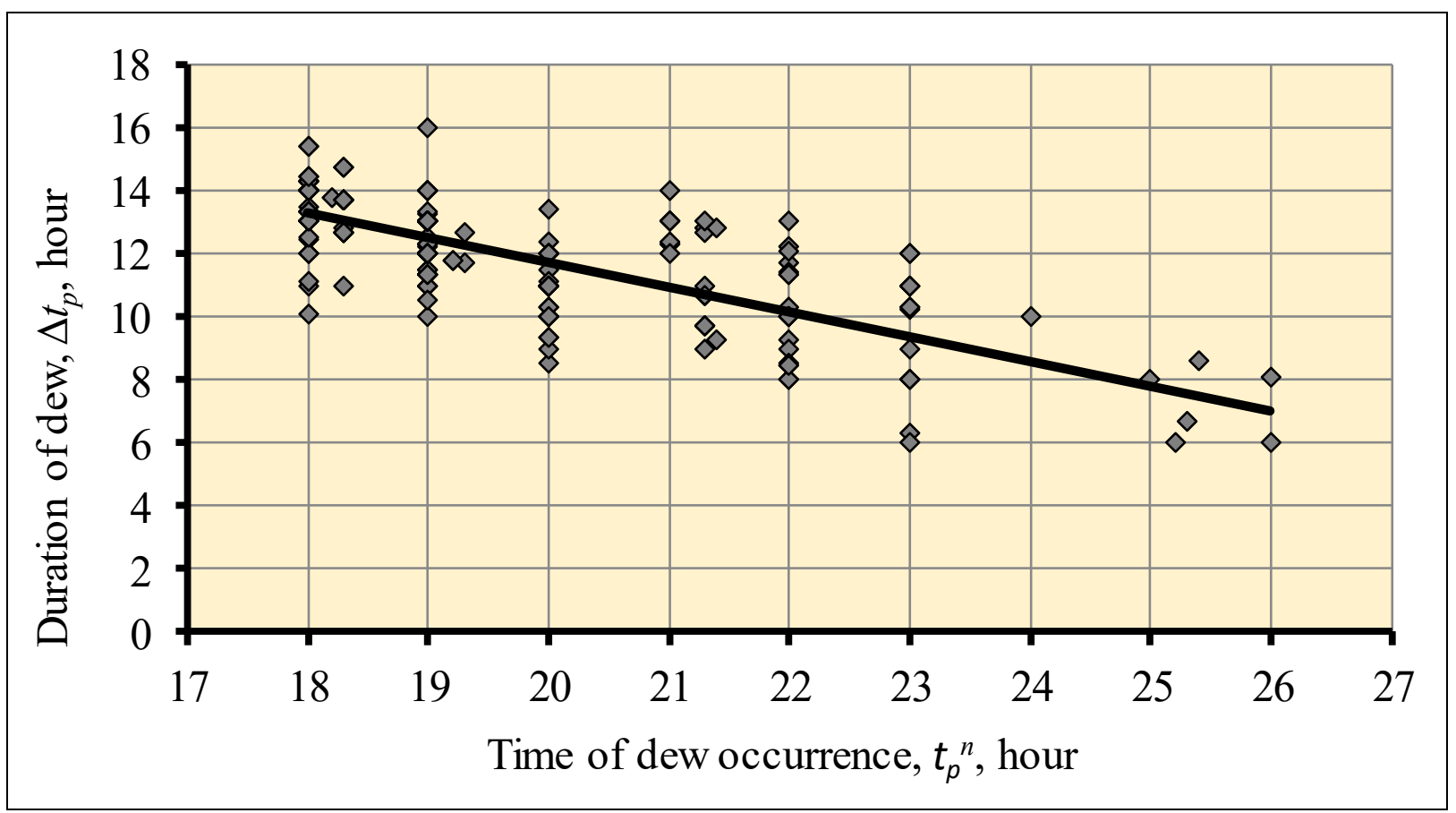

Graph 2: Correlation dependence of the duration of the dewy interval from the time of dew emergence

Source: the authors (2018)

In order to take into account in the model of the pendulous intervals of instability time $\Delta t_{p}$ of the regression line for fixed values $\left(t_{\text {пр }}\right)$, the deviation study $\left(\Delta t_{p}\right)$ was performed from its mean value. As a result, it was found that these deviations are described by the normal distribution law with the following basic statistical characteristics: 1) an estimate of mathematical expectation - $0.019 \mathrm{~h}$; 2) the estimation of the mean square deviation is 1,191 hours.

Thus, the model of the pink period of time in the system of events in the design environment is reflected by the time distribution of dew on the daily axis of time and the duration of the corresponding interval, which is determined by the mean value, which correlates with the time of dew appearance.

\subsection{Results of the justification of the model of air humidity deficit}

The graphoanalytic study of the change in the air humidity deficit was performed to justify the model of the corresponding dependence. The methodological feature of this study was that the statistical data on the change of this component of the project environment were grouped according to the criterion of the daily duration of the excess value of the deficit of air humidity $4 \mathrm{hPa}$. The data of changes in the air humidity deficit were analyzed for such intervals of the duration of the change in humidity deficit: 1) 6-10; 2) 10 - 14; 3) 14-18; 4) 18 - 22. 
DOI: 10.14807/ijmp.v10i7.922

The statistical processing of these data made it possible to establish that the corresponding dependence is described by a parabola, the characteristics of which vary from the admissible nature of the duration $\left(t_{\partial}\right)$ of the effective performance of harvesting during certain days (Graph 3 ).

One of the most important characteristics of the parabolic dependence of the air humidity deficit on the agrometeorologically permissible daily runtime efficiency of the harvesting operations is the maximum value of the humidity deficit $\left(D_{\max }\right)$. The processing of the collected statistical data on these indicators made it possible to establish the correlation dependence of the maximum value of the air humidity deficit $\left(D_{\max }\right)$ from the agro allowed during the day of the duration $\left(t_{i}\right)$ of the effective execution of the cutting operations:

$$
D_{\max }=3,725 e^{0,099 t_{\partial}} \text {. }
$$

The presence of this dependence, as well as the parabolic dependence of the air humidity deficit on agro-permeable during the days of the duration of the harvesting operations in the relevant projects, is the main reason for justifying the model of the air humidity deficit in the design environment. Such a model, obviously, should be a parabolic dependence of the change in air humidity deficit during the agro-permissible daily runtime of harvesting operations.

Let us assume that the initial value of this dependence coincides with the moment of the completion of dew in the early times. It is $4 \mathrm{hPa}$. The final value of this dependence coincides with the moment of dew decline in the afternoon and equals 4 $\mathrm{hPa}$. The maximum value of the air humidity deficit depends on the agro-approved during the day of the duration of the harvesting operations. To this end, we take the idealization that Dmax is detected in the middle of an agro-permissible daily time interval (td). Its value is determined from equation (3).

Thus, to show the dependence of the air humidity deficit $(D)$ on the agrotechnical tolerance $\left(t_{\partial}\right)$, the equation is used:

$D=a t_{\partial}^{2}+b t_{\partial}+c$,

where $a, b, c$ - parameters of parabola. 

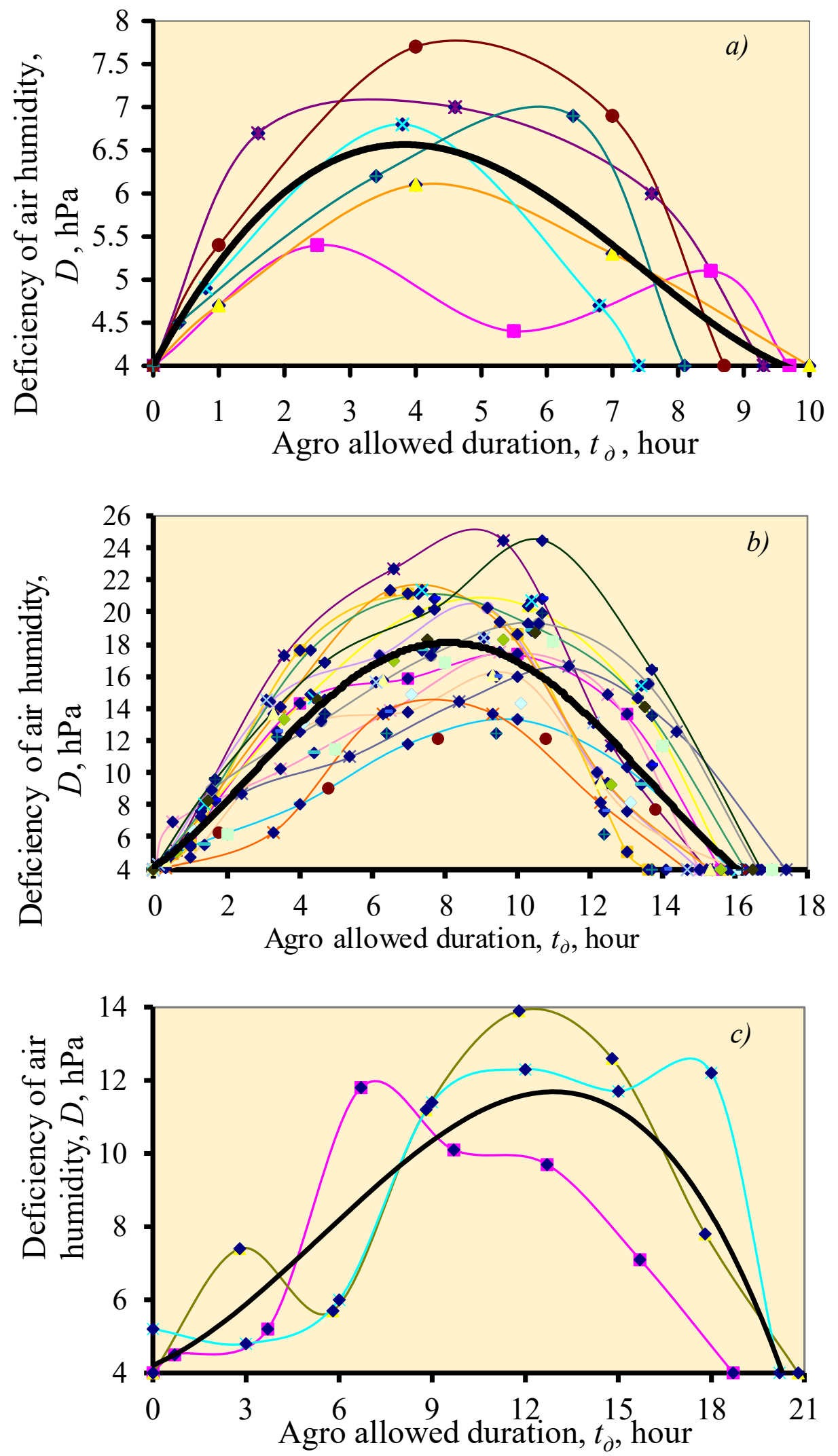

Graph 3: Empirical and theoretical dependence of the change in air humidity deficit on the agro-approved duration of harvesting operations: a) $t_{\partial}=6-10 \mathrm{~h}$; b) $t_{\partial}=14-18 \mathrm{~h}$;

c) $t_{\partial}=18-22 \mathrm{~h}$

Source: the authors, 2018 
DOI: 10.14807/ijmp.v10i7.922

Their numerical values are determined on the basis of solving the system of equations:

$$
\left\{\begin{array}{l}
c n+b \sum t_{\partial i}+a \sum t_{\partial i}^{2}=\sum D_{i} \\
c \sum t_{\partial i}+b \sum t_{\partial i}^{2}+a \sum t_{\partial i}^{2}=\sum t_{\partial i} \cdot D_{i}
\end{array}\right.
$$

where $\mathrm{n}$ is the number of known values $t_{\partial i}$ and $D_{i}$ respectively.

From this system of equations, we find:

$$
\begin{aligned}
& a=\frac{\sum t_{\partial i} \cdot D_{i} \sum t_{\partial i}-c\left(\sum t_{\partial i}\right)^{2}+c n \sum t_{\partial i}^{2}-\sum D_{i} \sum t_{\partial i}^{2}}{\sum t_{\partial i}^{3} \sum t_{\partial i}-\left(\sum t_{\partial i}^{2}\right)^{2}} \\
& b=\frac{\sum D_{i}-a \sum t_{\partial i}^{2}-c n}{\sum t_{\partial i}} .
\end{aligned}
$$

For our case we have $C=4 ; n=3$. In addition, for some days we have numerical values for the characteristic points of the parabola: $D_{1}=4, t_{\partial 1}=0$; $D_{2}=D_{\max }, t_{\partial 2}=\mathrm{t} / 2 ; D_{3}=4, t_{\partial 3}=t_{\partial}$.

Thus, for each value td, which is determined by the completion and deflection (occurrence) of the dew of a given period, is determined by the formula (3) $D_{\max }$, and the parameters of the parabola calculated by formulas (4) reflect the change in the time of the air humidity deficit.

\section{CONCLUSION}

The proposed methodology for justifying the models of a changing design environment is based on the analysis of official statistics of agrometeorological stations belonging to the territory of the implementation of harvesting projects for grain, oilseed and legume crops and involves the implementation of production experiments.

The pomaceous periods in the harvesting of early oilseeds, cereals and legumes are characterized by the probabilistic distribution of the time of dew emergence and its duration. This regularity and the established correlation relationship between the occurrence of dew and its duration are the main components of the corresponding model, which allows them to take into account 
DOI: 10.14807/ijmp.v10i7.922

these events in the process of content management and the timing of harvesting operations.

The air humidity deficit, in which the performance of harvesting is effective, changes over the course of the day with a parabolic dependence, the maximum value of which depends on the agro-approved duration of these works, which is the basis for justifying the model of the air humidity deficit and taking into account its impact on the work in the relevant projects.

The obtained results of the research are the basis of the development of simulation models of projects for the collection of early oilseeds, grain and legume crops to determine the use indicators and resource requirements for the implementation of these projects.

\section{REFERENCES}

AKKERMAN, R.; DONK, D. (2009) Analyzing scheduling in the food-processing industry: structure and tasks. Cognition, Technology and Work, v. 11, n. 3, p. 215226. Available at: <https://doi.org/10.1007/s10111-007-0107-7>. Access: 10 October 2018.

AMORIM, F. R.; SILVEIRA, B. R. F.; SANTOS, E. A.; ABREU, P. H. C.; TOSTES, J. R. (2017) Analysis of the economic viability of a rural tourism enterprise in Brazil: an application of the Monte Carlo Method. Independent Journal of Management \& Production. v. 8, n. 4, p. 1365-1380. DOI 10.14807/ijmp.v8i4.662.

ANDERSON, A. (1988) Factors affecting machinery costs in grain production. ASAE paper, n. 88, p. 1-10.

ANDRADE, E. L. (2009) Introdução à Pesquisa Operacional: métodos e modelos para a análise de decisão. $4^{a}$ Edição. Rio de Janeiro: LTC - Livros Técnicos e Científicos.

BENDOLY, E.; CROSON, R.; GONCALVES, P.; SCHULTZ, K. (2010) Bodies of knowledge for research in behavioral operations. Production and Operations Management, v. 19, n. 4, p. 434-452. Available at: <https://doi.org/10.1111/j.19375956.2009.01108>. Access: 25 October 2018.

BUSHEW, S. (2000) Project Management Leadership, 2 ed. Kiev: Delovaya Ukraina.

BUSHEW, S. (2009) Innovative Projects and Programs Management Guide, t.1, version 1.2. Kiev: Science. World.

CLELAND, D.; IRELAND, L. (2007) Project management handbook. Applying Best Practices across Global Industries. Mc Graw Hill.

FRAME, D. J. (1994) The New Project Management. San Francisco: Jossey-Bass Publishers. 
FRANSOO, J. C.; WIERS, V. C. (2006) Action variety of planners: cognitive load and requisite variety. Journal of Operations Management, v. 24, n. 6, p. 813-821. Available at: <https://doi.org/10.1016/j.jom.2005.09.008>. Access: 12 October 2018.

HEIZER, J.; RENDER, B. (1996) Production \& Operations Management: strategic and tactical decisions. 4th Edition. USA, New Jersey: Prentice Hall.

KERZNER, H. (2003) Project Management: A Systems Approach to Planning, Scheduling, and Controlling. $10^{\text {th }}$ ed. Wiley: John Wiley \& Sons, Inc.

LERMEN, H. F.; MORAIS, M. F.; MATOS, C.; RÖDER, R.; RÖDER, C. (2016) Optimization of times and costs of project of horizontal laminator production using pert/cpm technical. Independent journal of management \& production, v. 7, n. 3. Available: < ttp://www.ijmp.jor.br/index.php/ijmp/article/view/423/534>. Access: 20 October 2018.

PIERRE, N.; ROBILLARD, M.; ROBILLARD P. (2000) Types of collaborative work in software engineering.The Journal of Systems and Software, v. 53, p. 219-224.

ROMANO, L. N. (2003). Modelo de Referência para o Processo de Desenvolvimento de Máquinas Agrícolas. Tese (Doutorado em Engenharia Mecânica). Universidade Federal de Santa Catarina, Florianópolis. Available at: < http://emc6605.ogliari.prof.ufsc.br/uploads/artigos/tese_romano.pdf>. Access: 20 October 2018.

SILVEIRA, F.; MACHADO, F. M.; RUPPENTHAL, J. E.; ROMANO, L. N.; RODRIGUES, V. P.; FARIAS, M. S. (2018) Systematic analysis of reference models in product development: case studies in the agricultural machinery and implementation sector. Independent Journal of Management \& Production. v. 9, n. 2, p. 395-423. DOI 10.14807/ijmp.v9i2.754.

SYDORCHUK, O.; LUB, P.; TRYHUBA, A. (2011) Stochastic character of the naturally predicted optimal time of soil-tillage and plant- sowing works in the spring period. Motoryzacja i energetyka rolnictwa, v. 13, Lublin, p. 302-308.

SYDORCHUK, O.; TRYHUBA, A.; PANYURA, Y. A.; et al. (2012) Forecasting the basic events of the internal environment of harvesting early cereals, oilseeds and legumes. Scientific journal LNTU: Computer-integrated technologies: education, science, production, n. 10, p. 232-237.

SYDORCHUK, O. V.; TRYHUBA, A. M.; PANYURA, Y. A. (2010) Peculiarities of situational management of the content and time of execution of works in integrated projects of agrarian productionю. Eastern-European Journal of Enterprise Technologies: Control processes, v. 43, n. 1/2, p. 46-48. Available at: < http://journals.uran.ua/eejet/article/view/2507/2295>. Access: 26 October 2018.

TRYHUBA, A.; SHOLUDKO, P. (2011) Harmonization of works in integrated milk projects. Eastern-European Journal of Enterprise Technologies: Control processes, v. 49, n. 1/6, p. 13-16.

TRYHUBA, A.; SHOLUDKO, P.; MIHALYUK, M. (2012) Models of events of the agrometeorological component of the projects of chemical protection of plants by spraying. East European Journal of Advanced Technology, v. 11, n. 55, p. 44-47.

TRYHUBA, A.; SHOULDKO, P.; MALANCHUK, O. (2013) Formation of productiontechnological risk in integrated agricultural production programs. East European Journal of Advanced Technology, v. 10, n. 61, Part 3, p. 203-206. 
TRYHUBA, A.; ZACHKO, O.; GRABOVETS, V. (2018) Examining the effect of production conditions at territorial logistic systems of milk harvesting on the parameters of a fleet of specialized road tanks. Eastern-European Journal of Enterprise Technologies: Control processes, v. 95, n. 5/3, p. 59-70.

DOI: 10.15587/1729-4061.2018.142227.

TRYHUBA, A.; RATUSHNY, R.; BASHYNSKY, O. (2018) Identification of firefighting system configuration of rural settlements" Fire and Environmental Safety

Engineering. MATEC Web Conf., v. 247 (FESE 2018), p. 1-8.

DOI: https://doi.org/10.1051/matecconf/201824700035

TRYHUBA, A.; TRYHUBA, I.; BOYARCHUK, O. (2018) Identification of configuration of project environment and feed providing of family dairy farms projects. National technology University Journal, n. 1 (1277), p. 64-68. DOI: 10.20998/24133000.2018.1277.10 